$\sim$ Amira Bushra Ali Hassan

\title{
Investigating the Role of Voluntary Disclosure in Mitigating Information Asymmetry among Equity Investors in Concentrated Ownership Structures: An Empirical Study Amira Bushra Ali Hassan
}

\begin{abstract}
This research aims to investigate the association between ownership concentration, information asymmetry and voluntary disclosure. It analyzes the influence of ownership concentration as a corporate governance mechanism and examines its impacton information asymmetry. This research further investigates the impact of voluntary disclosure as a tool suggested by the literature to mitigate information asymmetry among controlling and minority investors in concentrated ownership structure. The results shows that ownership concentration in general is significantly positively associated with information asymmetry. The results also demonstrate that voluntary disclosure significantly attenuates information asymmetry in concentrated ownership structures.
\end{abstract}


يهدف البحث الي تحليل العلاقات بين تركز الملكية ، الأفصاح الأختياري، الملخص

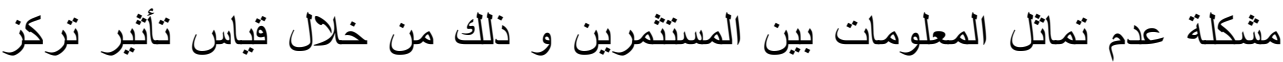

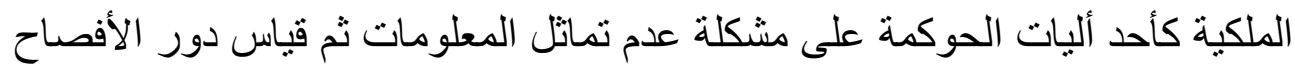
المحاسبي الأختياري في الحد من مشكلة عدم تمانل المعلومات في في هياكل في الماتل الملكية

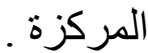

لقد أوضحت نتائج البحث ان تركز الملكية بزيد من مشكلة عدم تماتل المعلومات بينما يساهم الأفصاح المحاسبي الأختياري في الحد من مشكلة عدم تماتل المعلومات في هياكل الملكية المركزة. 
Investigating the Role of Voluntary Disclosure in Mitigating

Amira Bushra Ali Hassan

\section{Introduction}

Since Berle \& Means (1932) raised the issue of the separation of ownership and control, corporate governance has become a key research topic for a number of disciplines. The central premise of their work was the recognition of problems associated with the separation of ownership and management. Jensen \& Meckling, (1976) expanded these ideas significantly through the introduction of agency theory.

Agency theory was first predicated by Alchian \& Demsetz, (1972) who emphasized that activities of firms were governed by the role of contracts. Agency theory explains how best to organize relationships in which one party (principal) determines the work, which another party (agent) performs. The principalagent problem arises when the shareholders (principals) hire managers (agents) to make decisions that are in the best interests of the shareholders. The theoretical postulations continue that in general people are self-interested and will therefore have conflicts of interest in any cooperative endeavors (Jensen, 1994).

Agency theory asserts that conflicts in firm governance will occur between the firm principals (owners) and agents (managers) (Eisenhardt, 1989; Fama \& Jensen, 1983; Shleifer \& Vishny, 1997). Such conflict suggests the need for a number of governance mechanisms that may help to align the interests of shareholders and managers.Ownership concentration is a fundamental internal corporate governance mechanism suggested by a plenty of prior studies ( e.g Dyck \& Zingales, 2004; Faccio, Larry, \& Young, 2001). 
Investigating the Role of Voluntary Disclosure in Mitigating

Amira Bushra Ali Hassan

as an efficient monitoring mechanism to prevent managers from expropriating company resources for private benefit. Therefore, alleviates conflicts of interests between managers and shareholders. This argument of ownership concentration's beneficial function is referred as the efficient-monitoring hypothesis.

However, concentrated ownership structure is also associated with some potential costs including higher cost of capital due to lower market liquidity. Besides, it prevents additional monitoring by takeover markets. Further, it increases the potential of other severe agency problems between majority and minority investorsif the former find it advantageous to pursue private benefits of control and expropriate minority shareholders. This type of conflict is often referred to "principalprincipal agency problem".

Information asymmetry is one of the severe problem that oftenstems from inadequate information sharing (Stiglitz, 2002).It occurs when one party or more possess better informational awareness pertinent to effective participation in a given situation relative to other participating parties (Clarkson, Jacobsen, \& Batcheller, 2007). It arises between those who hold that information and those who could potentially make better decisions if they had it (Connelly, et al., 2011).

Information asymmetry adds to market friction and exerts influence on the cost of external finance, easily leading to insufficient investment for companies under liquidity constraint (Agarwal \& O’Hara, 2007). 
Investigating the Role of Voluntary Disclosure in Mitigating

Amira Bushra Ali Hassan

Corporate disclosure has been identified as one of the means suggested by literature for reducing information gap betweenthe firm and its shareholders. Therefore, improves efficiency of capital allocation and also reduces the uncertainty surrounding future corporate performance.

This research extends the prior literature of capital market based research in accounting in two ways. First it attempts to evaluate the role of ownership concentration as an internal corporate governance mechanism suggested by the literature to alleviate the conflict of interests and agency problems that arise from separation of ownership and control by classifying concentrated ownership structures into two mutually exclusive classes (i) institutional ownership, (ii) managerial ownership based on the identity of large blockholder ${ }^{1}$. Then measuresthe impact of each class on information asymmetry problem among equity investors in capital market. Second, this research shed the light on the role of voluntary disclosure in capital market through measuring its impact on information asymmetry problem specifically in concentrated ownership structures.

The remainder ofthis paper is organized as follow: Section two provide a review of prior studies addressing the main variables of the research, draw outthe hypothesesfortesting. Section three identifies the research methods applied including sample selection procedures, data sources and variable measurement.

Section four outline the empirical study conducted, data analysis, statistical techniques applied and the main results. 
Investigating the Role of Voluntary Disclosure in Mitigating

Amira Bushra Ali Hassan

Section five concludes the paper and makes recommendations for further research.

\section{Literature Review and Hypotheses Development}

\subsection{Ownership Concentration and Information Asymmetry}

In theory, ownership concentration can produce two opposing effects on information asymmetry between controlling shareholders and minority investors, depending on whether the managerial entrenchment effect or the incentive alignment effect dominates their trading behavior in capital market. According to Adverse selection theory Ownership concentration can increase private information events, resulting in uninformed traders possibly facing a higher trading risk against informed traders who could exploit minority investors.

On the contrary, the presence of controlling investors can increase the efficiency with which information is reflected in market prices. The information efficiency theory predicts that informed investors' private information enables them to actively participate in markets, and their trading helps to disseminate their more timely and detailed information to the market which makes stock prices more informative.

There is a lack of empirical studies that directly test the relationship between ownership concentration and information asymmetry problem in capital market. Most of the prior studies support the existence of a significant positive association between ownership concentration and information asymmetry problem.

The empirical results of (Byun, Hwang, \& Lee, 2011; Boujelbéne \& Bouri, 2011; Attig, et al., 2006) are consistent with 
Investigating the Role of Voluntary Disclosure in Mitigating

$\sim$ Amira Bushra Ali Hassan

the management entrenchment hypothesis. That more concentrated control by the largest shareholder exacerbates the information asymmetry problem between insiders and outside shareholders. This negative effect is more sever for countries with relatively low levels of minority investor protection (Attig, et al., 2006). On the contrary, Khorramin, Asghari, \& Nia (2014) find no significant association between ownership concentration and information asymmetry.

The prior studies showed mixed results regarding the relationship between ownership concentration and information asymmetry as a result the researcher set the first hypothesis as follows:

$\mathrm{H}_{01}$ There is no significant association between information asymmetryand ownership concentration.

This hypothesis is divided into the following sub-hypotheses to incorporate the impact of identity of shareholder

$\mathrm{H}_{01 \mathrm{a}}$. There is no significant association between information asymmetry and institutional-controlled concentrated ownership structure.

$\mathrm{H}_{01 \mathrm{~b}}$. There is no significant association between information asymmetry and Management controlled concentrated ownership structure.

2.2. Voluntary Disclosure, Information Asymmetry and

\section{Ownership Concentration}

Economic theory suggests that disclosure reduces information asymmetry through two channels: disclosure directly lowers the amount of private information relative to publicly available information, and it indirectly reduces private 
Investigating the Role of Voluntary Disclosure in Mitigating

Amira Bushra Ali Hassan

information search incentives by reducing the expected benefits of private information, it also alters the trading behavior of both uninformed and informed investors (Brown, Hillegeist \& Lo, 2004).A firm's disclosure reduces the asymmetric information risk from the perspectives of uninformed investors by altering the distribution of public and private information among investors. It reduces the informational advantage of pre-informed agents, and therefore the extent of information asymmetry (Gajewski \& Quéré, 2013).

Most of the prior studies that empirically investigate the impact of the level of voluntary disclosure on information asymmetry problem support the existence of a significant negative association between the two variables (Cheng, courtenay, \& Krishnamurti, 2006; Petersen \& Plenborg, 2006 ; Chen, , et al., 2007; Cormier, et al., 2010).Lakhal, (2008) examined the impact of two categories of voluntary disclosure with different attributes (i.e., quarterly earnings disclosures and earnings forecast) on information asymmetry, the findings reveal that while the quarterly earnings reduce information asymmetry, earnings forecasts exacerbate information asymmetry before and after the announcement date which indicate that the type of information disclosed has important implications on information asymmetry.

There is a lack of prior studies that attempt to investigate the association between ownership concentration, information asymmetry, and voluntary disclosure. Jiang, Habib, \& Hub, (2011) found that the relationship between ownership concentration and information asymmetry is conditional upon the 
Investigating the Role of Voluntary Disclosure in Mitigating

Amira Bushra Ali Hassan

level of voluntary disclosure in newZealand. The following testablehypothesis is developed to empirically examine the moderating effect of voluntary disclosure on the relationship between ownership concentration and information asymmetry.

$\mathrm{H}_{02}$ : there is no significant impact of voluntary disclosure on the relationship between ownership concentration and information asymmetry.

\section{The Research Methods}

\subsection{Sample Selection}

The population of the study consists of all companies listed on the Egyptian stock Exchange whose total number is 210 companies by the end of year 2013. Due to lack of a comprehensive database of all information required for the study, a sample of the most actively Traded over the period (2009-2013) was selected because their recent data are available for researchers and investors. The selection of the items to be included in the sample was based on a list provided by the Egyptian Company for Information Dissemination (EGID) that represent the most actively traded companies according to their market capitalization and a set of criteria that should be satisfied in the in the company to be included in the sample. These criteria are as follow:

-The listed Company included in the sample should not belong to any of these two sectors (i.e. banks, financial institutions excluding banks) because such companies are subject to further regulations of disclosure, hence their annual reports may be not comparable to those of other companies. 
Investigating the Role of Voluntary Disclosure in Mitigating

Amira Bushra Ali Hassan

- The Company's trading currency is the Egyptian pound (L.E). companies whose trading currency is different from the Egyptian pound are excluded from the sample.

-The availability of the required financial, non-financial, and capital market information for selected companies over the period 2009-2013.

The final sample consists of 55 nonfinancial most actively traded companies over the period 2009 to 2013 with a total number of observations 275. This figure was arrived at after a number of refinements to the original list due to changes in some companies' legal status, and data available

\subsection{Data sources}

The data used was collected from a variety of sources. The annual reports, in addition to the board of director's reports, bidask prices, daily trading volume, closing stock prices, and the detailed

information regarding firm's ownership structure of the listed companies were obtained from the Egypt Company for Information Dissemination (EGID).The annual disclosure books for the years (2009-2012) were obtained from the public relations at Egyptian stock of Exchange (EGX). The Listing and disclosure Rules issued by the Egyptian Financial Supervisory Authority in addition to disclosure forms were available through the official web site of the Egyptian stock of exchange (EGX). 
Investigating the Role of Voluntary Disclosure in Mitigating

Amira Bushra Ali Hassan

Variable Measurement

\subsubsection{Information Asymmetry}

Information asymmetry phenomenon is not directly observable (Jiang \& Kim, 2004; Lu, Chen, \& Liao, 2010). Various proxies, including (bid- ask spread, trading volume, stock price volatility and probability of informed trading) have been identified by prior studies to empirically measure information asymmetry. Following Jiang, Habib \& Hub, ( 2011), this research uses the bid-ask spread on annual report release date to assess the level of information asymmetry.This research follows Yoon, Zo \& Ciganek (2011) ; Fu, ArthurKraft \& HuaiZhang (2012) and employ the relative quoted spread as a proxy measure for information asymmetry, which represent the difference between the price quoted by buyers and the price quoted by sellers for a given security at a particular point of time and it can be computed using the following formula:

$$
\text { Spread }=\frac{\text { Ask Price }- \text { Bid Price }}{\frac{\text { (Ask Price }+ \text { Bid Price })}{2}}
$$

In the presence of information asymmetry uninformed investors lower (increase) the price at which they are willing to buy (sell) to protect against the expected losses from trading with an informed counterparties. The more severe the information asymmetry, the wider the spread necessary to cover higher expected market participant's losses from probability of trading with informed investors (Fu, ArthurKraft \& HuaiZhang, 2012). 


\subsubsection{Ownership Concentration}

The current study uses Herfindahl index to measure the firm's level of ownership concentration. The index is calculated by summing up the squared percentage of shares owned by the blockholder.Following Clark \& Wójcik, 2003; Jiang \& Habib, 2009; Jiang, Habib \& Hub, 2011), the Herfindah Index is calculated using the following formula:

$$
H=\sum_{i}^{N} S_{i}^{2}
$$

Where;

$N$ is the number of largest shareholders

$S$ is the percentage of shares owned by each of the largest blockholders

The $\mathrm{H}$ index ranges from zero to one with larger values indicating more concentrated ownership. Dummy variables are used to identify two different types of ownership concentration which are (i) financial institution-controlled (FDUM) ;(ii) management-controlled (MDUM).MDUM is coded 1 when ownership concentration is Management-controlled and 0 otherwise. This procedure results in 30, 54, firm-year observations for financial institutions, management controlled ownership structures A company is categorized as having one of two mutually exclusive shareholding structures when that particular type of blockholder holds the largest proportion of the largest shareholdings. 
Investigating the Role of Voluntary Disclosure in Mitigating

$\sim$ Amira Bushra Ali Hassan

\subsubsection{Voluntary Disclosure}

A self-constructed unweighted voluntary disclosure index is used to measure the level of voluntary disclosure on the annual reports for companies listed on the Egyptian Stock of Exchange. The constructed index focus on investors' information needs and the selection of items is based on the prior studies of (Botosan, 1997; Eng \& Mak 2003; Petersen \& Plenborg 2006; Elsayed \& Hoque, 2010; Samaha \& Dahawy, 2011; Ismail \& El-Shaib, 2012; Samaha, et al., 2012; Ho \& Taylor, 2013; Soliman, 2013; Kumar G., 2013; Gisbert \& Navallas,2013) .

To ensure the content validity of the disclosure index, the items of the constructed disclosure index were checked against the mandatory requirements under the Egyptian accounting Standards (EASs) and the disclosure rules issued by the Egyptian stock of exchange in order to make sure that the index reflects only voluntary disclosure. The constructed index is divided into five major subparts representing the categories of voluntary disclosure, resulting in a total of 50 disclosure items (see table 3.1).The items of information of the index are numerically scored on a dichotomous basis which assigns a score of "1" if a company discloses an item and a score of "0" if it does not (Huafang \& Jianguo, 2007;Hossain \& Hammami, 2009 ; Soliman, 2013 ) .

Each firm's overall voluntary disclosure index score (VDSCORE) is computed as a ratio of the actual score awarded to the firm divided by the maximum score attainable. the computed disclosure score is derived from the annual report, board of directors report obtained from the Egyptian Company for Information Dissemination (EGID) as well as the annual 
disclosure books for the years (2009-2012) issued by the Egyptian Stock of Exchange (EGX).

Following Hossain \& Hammami, (2009); Uyar \& Kılıç, (2012), the firm's voluntary disclosure index can be mathematically represented through the following formula:

$$
\text { VDcore }=\sum_{j=1} \frac{d j}{n}
$$

Where;

VDscore: is the aggregate disclosure.

$d j=1$ if item $\mathrm{j}$ is disclosed and 0 if the item $\mathrm{j}$ is not disclosed.

$n$ : is the maximum score each firm could attain.

\section{table (3.1) items of disclosure index}

Voluntary Disclosure Items

\section{Strategic Information}

\section{A.1 General Corporate Information}

Brief history of the company

Organizational structure/chart

General description of business/activities

Principal products/services

Principal markets

Competitive environment

Significant events calendar

\section{A.2 Corporate Strategy}

Vision and mission statement 


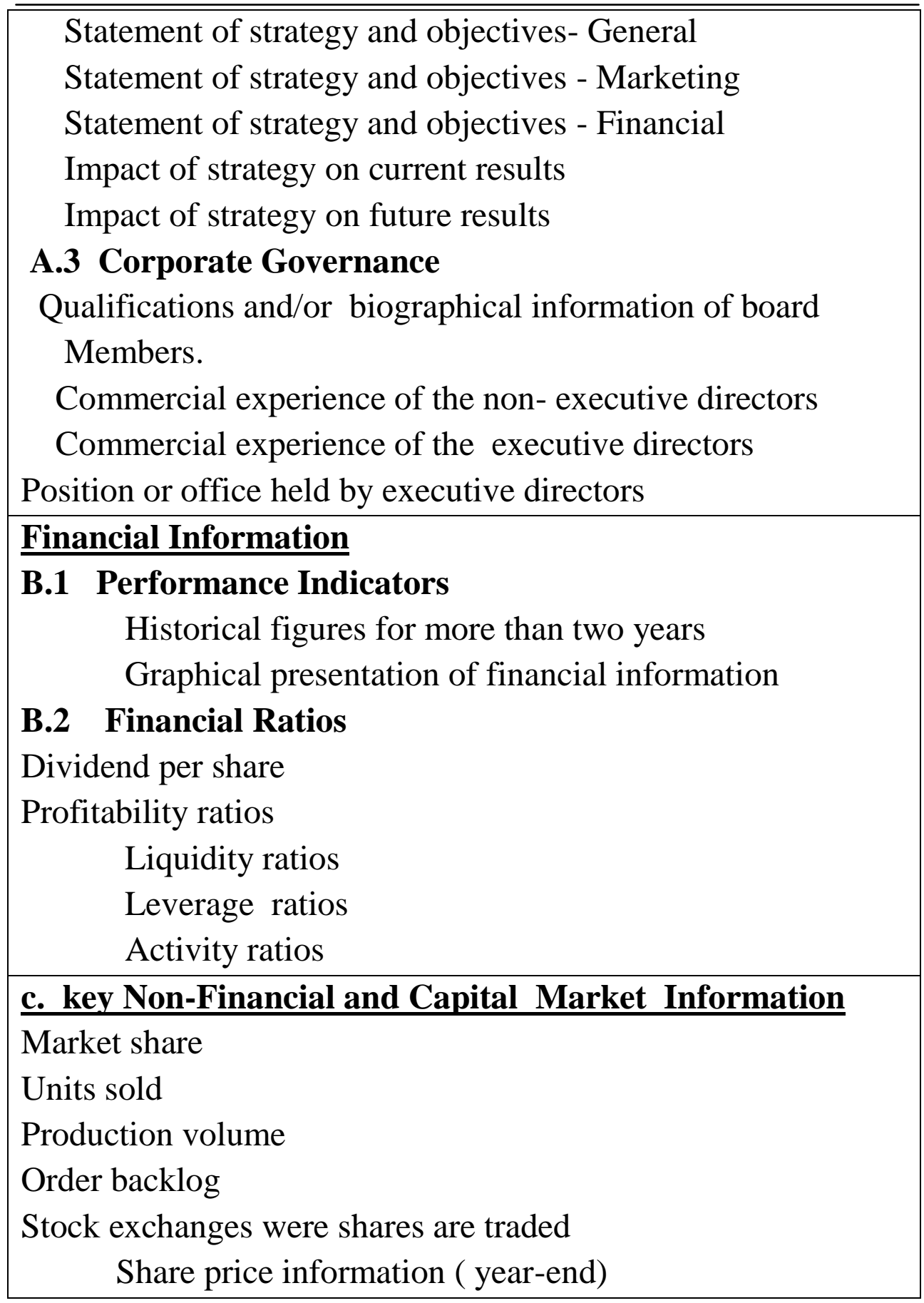


Investigating the Role of Voluntary Disclosure in Mitigating

$\sim$ Amira Bushra Ali Hassan

\begin{tabular}{|l}
\hline Share price information ( trend) \\
Volume of shares traded ( year-end) \\
Market capitalization ( year-end) \\
Graphical presentation of key non-financial \\
\hline D, Intangibles and Intellectual Capital Information \\
Human capital: training programs (total investment) \\
Human capital: training programs (policy/nature of \\
programs ) Human capital: training programs ( number or \\
Percentage of employees attending programs) \\
Human capital: health and safety \\
Relational capital: customer satisfaction index \\
Relational capital: environmental protection \\
programs \\
Structural capital : quality certificates \\
Structural capital: description of R\&D activities \\
\hline Forward Looking Information \\
Sales forecast \\
Earnings forecast \\
Cash flow forecast \\
Projected Capital expenditures and/or R\&D \\
Assumptions underlying the forecast \\
Discussion of future industry trend \\
expenditures
\end{tabular}


Investigating the Role of Voluntary Disclosure in Mitigating

Amira Bushra Ali Hassan

following (Botosan ,1997; Aly, 2008 ; Abdel-Fattah , 2008 ; Hassan, et al., 2009; Soliman, 2013), this study uses Cronback Alpha test to assess the reliability and validity of the index . the results of cronback alpha test shows the reliability of the disclosure index is about $86.7 \%$ and the validity is about $93.1 \%$ which confirm the high degree of reliability and validity of the index in estimating the level of voluntary disclosure.

\subsubsection{Control Variables}

The Control variables used in the regression model can be separated into two variables: one is related to firm characteristics (firm size) and the other is share turnover ratio used as an indicator of firm's liquidity.

\section{A. Firm Size}

The findings in the literature suggest that firm size is negatively associated with various proxies of information asymmetry (e.g. Leuz \& Verrecchia, 2000; Yoon, Zo, \& Ciganek, 2011; Jiang, Habib, \& Hub, 2011).Firm size is incorporated as a control variable following the argument that large companies will produce and distribute more information compared to their small firm counterparts.Firm size is measured as the natural logarithm of market value of equity at the end of the financial year and denoted as $\ln$ (MKVAL). Firm's market value is calculated using the following equation.

$M K V A L=N$ of Outstanding Shares ${ }^{*}$ Closing Stock Price

\section{B. Share Turnover Ratio}

The empirical results of prior studies support the existence of a negative association between share turnover ratio and information asymmetry (e.g. Cheng, courtenay \& Krishnamurti, 
Investigating the Role of Voluntary Disclosure in Mitigating

$\sim$ Amira Bushra Ali Hassan

2006; Petersen \& Plenborg, 2006; Yoon, Zo \& Ciganek, 2011).Share turnover ratio is calculated through dividing the daily trading volume by the firm's number of outstanding shares which is expressed mathematically through the following formula:

Share Turnover Ratio $(S T V O R)=\frac{\text { trading volume }}{N \text { of outstanding shares }}$

\section{Data analysis and Empirical Results}

\subsection{Descriptive Statistics}

Table (4.1) Descriptive Statistics

\begin{tabular}{|c|c|c|c|c|c|c|}
\hline variable & $\mathrm{N}$ & $\begin{array}{c}\text { Minimu } \\
\mathrm{m}\end{array}$ & $\begin{array}{c}\text { Maximu } \\
\mathrm{m}\end{array}$ & Mean & median & $\begin{array}{c}\text { Std. } \\
\text { Deviation }\end{array}$ \\
\hline spread & 275 & $-2.0000-$ & 2.0000 & .105518 & .0462919 & .7404200 \\
CONC & 275 & .0030 & 1.0000 & .268852 & .1896252 & .2601587 \\
VDSCOR & 275 & .0200 & .5200 & .159418 & .1400000 & .1050357 \\
$\mathrm{E}$ & & & & & & \\
In(MKVL) & 275 & 17.1690 & 24.1540 & $\mathbf{2 0 . 3 4 2 7 2 2}$ & $\mathbf{2 0 . 0 0 2 6 6 4 7 2}$ & 1.6008590 \\
STOVL & 275 & .0000 & $\mathbf{8 . 9 5 8 4}$ & .907789 & $\mathbf{0 . 2 2 1 6 0 7 9 7 9}$ & 1.5007133 \\
Valid N & 275 & & & & & \\
\hline
\end{tabular}

The statistics for all variables are based on 275 valid observations with non-missing values. Except firm size most of the variables of interest exhibit large divergences across the firms in the sample, this is noticed through the high values of standard deviation; The minimum and maximum values of the variables indicate that data points are spread out over a large range of values.

The mean of the relative bid ask spread (Spread) is 0.105 with minimum value -2.00 and maximum value 2.00 which 
Investigating the Role of Voluntary Disclosure in Mitigating

$\sim$ Amira Bushra Ali Hassan

indicate high variation between companies regarding the information asymmetry.

concentration (CONC) measured by the Herfindahl index has a mean value of 0.268 and ranges from 0.003 to 1.00 . The USA Department of Justice states that a Herfindahl index above 0.18 within an industry indicates high concentration, within $0.10-0.18$ indicates moderate concentration while an $\mathrm{H}$ below 0.1 indicates insignificant concentration (Jiang \& Habib, 2009 ;Jiang, Habib, \& Hub, 2011).

The mean Herfindahl index of 0.268 in the present study suggests a concentrated ownership pattern for the listed firms. The median values are interpreted as $50 \%$ of the companies have a concentration level above 0.18 which imply that ownership structure for sample companies is highly concentrated.

The voluntary disclosure index and their ranges suggest that the overall voluntary disclosure level is very low. The highest disclosure score obtained is $52 \%$ and the lowest is $2 \%$. The mean disclosure score is $15 \%$ which indicate that in general the level of voluntary disclosure in annual reports is very low which is also supported through the median value of (14\%) which indicates that $50 \%$ or half of the companies has a voluntary disclosure score below (14\%) the results are consistent with prior research on disclosure in the developing countries, specifically Egypt (Samaha \& Dahawy, 2011; Ismail \& El-Shaib, 2012; Soliman, 2013).

\subsection{Statistical techniques applied}


Investigating the Role of Voluntary Disclosure in Mitigating

$\sim$ Amira Bushra Ali Hassan

Ordinary least square regression (OLS) was used to test the hypotheses of the study. Two regression models were estimated.The first regression model examine the impact of various classes of ownership concentration on information asymmetry among equity investor. Further it measures the impact of voluntary disclosure on information asymmetry. The second model investigates the role of voluntary disclosure as a moderating variablethat could affect the relationship between ownership concentration and information asymmetry.

\subsection{Multivariate Analysis}

Table (4.2) Regression Coefficients (Model 1)

\begin{tabular}{|c|c|c|c|c|c|}
\hline \multirow{2}{*}{ Model } & \multicolumn{2}{|c|}{$\begin{array}{c}\text { Unstandardized } \\
\text { Coefficients }\end{array}$} & \multirow{2}{*}{$\begin{array}{c}\begin{array}{c}\text { Standardized } \\
\text { Coefficients }\end{array} \\
\text { Beta }\end{array}$} & \multirow{2}{*}{$\mathbf{t}$} & \multirow{2}{*}{ Sig. } \\
\hline & B & $\begin{array}{l}\text { Std. } \\
\text { Error }\end{array}$ & & & \\
\hline (Constant) & 1.862 & 1.163 & & 1.601 & .111 \\
\hline $\ln (\mathbf{M K V A L})$ & -.213 & .058 & -.265 & -3.653 & $.000 *$ \\
\hline STOVR & -.192 & .056 & -.228 & -3.421 & $.001 *$ \\
\hline CONC & .692 & .417 & .116 & 1.659 & $\begin{array}{c}.098 * \\
* *\end{array}$ \\
\hline VDSCORE $^{2}$ & -1.388 & .818 & -.113 & -1.697 & $\begin{array}{c}.091 * \\
* *\end{array}$ \\
\hline $\begin{array}{c}\text { CONC*FD } \\
\text { UM }\end{array}$ & 2.384 & 1.763 & .085 & 1.352 & .178 \\
\hline $\begin{array}{c}\text { CONC*MD } \\
\text { UM }\end{array}$ & .624 & .641 & .065 & .973 & .332 \\
\hline
\end{tabular}

Dependent Variable: $\ln$ ( spread)

* At a significance level less than or equal 0.01

*** At a significance level less than or equal 0.1 
Investigating the Role of Voluntary Disclosure in Mitigating

$\sim$ Amira Bushra Ali Hassan

As illustrated through the table ownership concentration (CONC) in general is significantly positively associated with bid ask spread (Ln spread) as a proxy of information asymmetry. That more concentrated control by the largest shareholder exacerbates the information asymmetry problem between insiders and outside shareholders.Hence, the first null hypothesis $\left(\mathrm{H}_{01}\right)$ that there is no significant association between information asymmetry and ownership concentration isrejected.

The identity of large shareholders has no significant impact on information asymmetry which is illustrated through the non-significant positive regression coefficients $(2.384, .624)$ of the interacting variables (CONC*MDUM, CONC*FDUM) for institutional controlled ownership structure and management controlled ownership structure. Hence the null sub-hypothesis $\left(\mathrm{H}_{01 \mathrm{a}}, \mathrm{H}_{01 \mathrm{~b}}\right)$ that there is no association between management controlled and institutional controlled ownership structure and information asymmetry are accepted.

The negative coefficient $(-1.388)$ indicates that the level voluntary disclosure is significantly negatively associated with bid ask spread that a commitment to more voluntary disclosure reduces information asymmetries.

Regarding the results of the control variables, the significant negative coefficient of MKVAL (-.213) illustrates that firm size measured by the natural $\log$ of market capitalization is significantly negatively associated with the proxy of information asymmetry which is consistent with the findings of (e.g. Leuz \& Verrecchia, 2000; (Yoon, Zo, \& Ciganek, 2011; Jiang, Habib, \& Hub, 2011). 
Investigating the Role of Voluntary Disclosure in Mitigating

Amira Bushra Ali Hassan

Also firm's stock liquidity measured by share turnover ratio(STVOR) is shown to have a significant negative association with information asymmetry which is consistent with the prior studies of (e.g. Cheng, courtenay, \& Krishnamurti, 2006; Petersen \& Plenborg, 2006; Yoon, Zo, \& Ciganek, 2011).

Goodness of Fit Statistics for the Regression (Model 1)

Table (4.3) provides insights regarding the overall fit of the regression models applied.

\section{Table (4.3) overall fit of the Regression (Model 1)}

\begin{tabular}{|c|c|c|c|c|}
\hline \multicolumn{5}{|c|}{ Panel A : $\mathbf{R}^{2}$ (coefficient of determination) } \\
\hline \multicolumn{5}{|c|}{$\begin{array}{c}\text { Model Summary } \\
\end{array}$} \\
\hline Mode & $\mathbf{R}$ & R Square & $\begin{array}{l}\text { Adjusted } \\
\text { R Square }\end{array}$ & $\begin{array}{l}\text { Std. Error } \\
\text { of the } \\
\text { Estimate }\end{array}$ \\
\hline $\mathbf{1}$ & $.382^{a}$ & .146 & .124 & 1.21937 \\
\hline
\end{tabular}

a. Predictors: (Constant), CONC, CONC*MDUM, STOVR, CONC*FDUMIT, VDSCORE, $\ln (M K V A L)$

b. Dependent variable: In (Spread)

\section{Panel B : F -Test}

ANOVA ${ }^{0}$

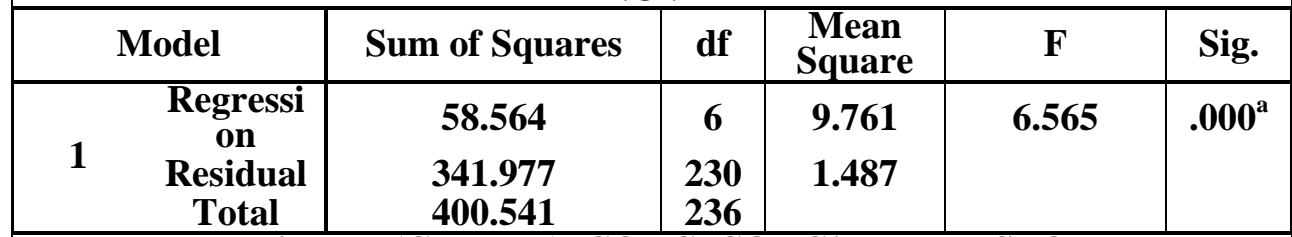

a. a. Predictors: (Constant), CONC, CONC*MDUM, STOVR, CONC*FDUMIT, VDSCORE, $\ln (\mathrm{MKVAL})$

b. Dependent Variable: In (Spread)

Panel C :T-Test

\begin{tabular}{|c|c|c|}
\hline Model & $\mathbf{t}$ & Sig. \\
\hline 1 & & $\mathbf{. 1 1 1}$ \\
\hline
\end{tabular}

ملية العقد الثخانيه 10 
Investigating the Role of Voluntary Disclosure in Mitigating

$\sim$ Amira Bushra Ali Hassan

\begin{tabular}{|c|c|c|}
\hline In(MKVAL) & $\mathbf{- 3 . 6 5 3}$ & $\mathbf{. 0 0 0}$ \\
STOVR & $-\mathbf{3 . 4 2 1}$ & $\mathbf{0 0 1}$ \\
CONC & $\mathbf{1 . 6 5 9}$ & $\mathbf{. 0 9 8}$ \\
VDSCORE & $\mathbf{- 1 . 6 9 7}$ & $\mathbf{. 0 9 1}$ \\
CONC*FDUM & $\mathbf{1 . 3 5 2}$ & $\mathbf{. 1 7 8}$ \\
CONC*MDUM & .973 & .332 \\
\hline
\end{tabular}

Dependent Variable: $\ln ($ Spread $)$

\begin{tabular}{|c|c|c|}
\hline \multicolumn{3}{|l|}{ Panel (D): Multi-collinearity } \\
\hline \multirow{2}{*}{ Model } & \multicolumn{2}{|c|}{ Collinearity Statistics } \\
\hline & Tolerance & VIF \\
\hline $\begin{array}{c}\text { (Constant) } \\
\text { In(MKVAL) } \\
\text { STOVR } \\
\text { CONC } \\
\text { VDSCORE } \\
\text { CONC*FDUM } \\
\text { CONC*MDUM }\end{array}$ & $\begin{array}{l}.703 \\
.838 \\
.763 \\
.831 \\
.948 \\
.833\end{array}$ & $\begin{array}{l}1.423 \\
1.194 \\
1.311 \\
1.203 \\
1.055 \\
1.200\end{array}$ \\
\hline
\end{tabular}

Dependent Variable: $\ln ($ Spread)

Although as illustrated through panel (A), the regression model explains only around (14.6\%) of the total variation of information asymmetry. Panel (B) indicates that the regression model is statistically significant with $\mathrm{F}$ value $(6.565)$, at a significance level less than (0.01). The results of ANOVA test show that the R-and R-squared of the model are significant, even if they are low in value, This indicates that, overall, the suggested regression model can statistically significantly predict the dependent variable.

The T-test determines the significance of each independent variable in the regression model. Panel (C) shows the results of T-test for the first regression model applied. The significant independent variables accepted in model (1) are ownership 
Investigating the Role of Voluntary Disclosure in Mitigating

Amira Bushra Ali Hassan

concentration, firm size, stock liquidity, voluntary disclosure at a significance level less than or equal (0.1), (0.01), (0.01), (0.1).

The remaining variables (CONC*MDUM,CONC*FDUM) are non-significant at a significance level more than (0.1).

Panel (D) shows the results of two diagnostic factors used to assess whether collinearity is problematic in the regression model applied in the current study.

Tolerance and variance inflation factor (VIF) are the two multi-collinearity diagnostic factors conducted. Tolerance of less than ( 0.1 or 0.2$)$ and VIF above (5 or 10$)$ are indicators of multicollinearity.

As shown through panel $D$ all the independent variables has a tolerance value greater than $(0.2)$ and VIF value less than (5) which indicates the existence of some correlation, but inconsequential multi-collinearity.

\section{Table (4.4) Regression Coefficients (Model 2)}

\begin{tabular}{|c|c|c|c|c|c|}
\hline \multirow[t]{2}{*}{ Model } & \multicolumn{2}{|c|}{$\begin{array}{c}\text { Unstandardized } \\
\text { Coefficients } \\
\end{array}$} & \multirow{2}{*}{$\begin{array}{c}\begin{array}{c}\text { Standardized } \\
\text { Coefficients }\end{array} \\
\text { Beta }\end{array}$} & \multirow[t]{2}{*}{$\mathbf{t}$} & \multirow[t]{2}{*}{ Sig. } \\
\hline & B & Std. Error & & & \\
\hline (Constant) & 3.491 & 1.599 & & 2.184 & .031 \\
\hline CONC & 1.128 & .663 & .193 & 1.702 & .092 \\
\hline $\begin{array}{c}\text { VDSCOR } \\
\mathbf{E}^{3}\end{array}$ & -2.345 & 1.676 & -.143 & -1.399 & .164 \\
\hline $\begin{array}{c}\ln (\text { MKVA } \\
\text { L) }\end{array}$ & -.334 & .077 & -.483 & -4.357 & .000 \\
\hline STOVR & -.203 & .067 & -.295 & -3.042 & .003 \\
\hline $\begin{array}{l}\text { CONC*V } \\
\text { DSCORE }\end{array}$ & -.400 & .201 & -.170 & -1.989 & .049 \\
\hline
\end{tabular}

Table (4.4) illustrate the results of incorporating the impact of corporate disclosure as a moderating variable in the regression analysis through the interacting variable (CONC*VDSCORE). 
Investigating the Role of Voluntary Disclosure in Mitigating

Amira Bushra Ali Hassan

The significant negative coefficient $(-.421)$ of the interaction term (CONC*VDSCORE) indicates that Voluntary disclosure is statistically significant moderator for the linear relationship between ownership concentration and information asymmetry that increase in the level of voluntary disclosure by firms with concentrated ownership structures mitigates information asymmetry. Hence, the second null hypothesis (H02) that there is no significant association between information asymmetry and voluntary disclosure-ownership concentration variable is rejected and that the relationship between ownership concentration and information asymmetry is conditional upon the level of voluntary disclosure.

\section{Goodness of Fit Statistics for the Regression (Model 2)}

Table (4.5) overall fit of the Regression (Model 2)

Panel A : $\mathbf{R}^{2}$ (coefficient of determination)

Model Summary

\begin{tabular}{|c|c|c|c|c|c|}
\hline Mode & & $\mathbf{R}$ & R Square & $\begin{array}{l}\text { Adjusted } \\
\text { R Square }\end{array}$ & $\begin{array}{c}\text { Std. Error } \\
\text { of the } \\
\text { Estimate }\end{array}$ \\
\hline & 2 & $.466^{a}$ & .217 & .183 & 1.08272 \\
\hline
\end{tabular}

a. Predictors: (Constant), CONC*VDSCORE, VDSCORE, STOVR, $\ln$ (MKVAL), CONC

d. Dependent variable: In (Spread)

\section{Panel B : F -Test}

\begin{tabular}{|cc|c|c|c|c|c|}
\hline \multicolumn{7}{|c|}{ ANOVA $^{\mathrm{b}}$} \\
\hline Model & $\begin{array}{c}\text { Sum of } \\
\text { Squares }\end{array}$ & df & $\begin{array}{c}\text { Mean } \\
\text { Square }\end{array}$ & F & Sig. \\
\hline 2 & $\begin{array}{c}\text { Regre } \\
\text { ssion }\end{array}$ & 36.751 & 5 & 7.350 & 6.270 & $.000^{\mathrm{a}}$ \\
\hline
\end{tabular}


Investigating the Role of Voluntary Disclosure in Mitigating

Amira Bushra Ali Hassan

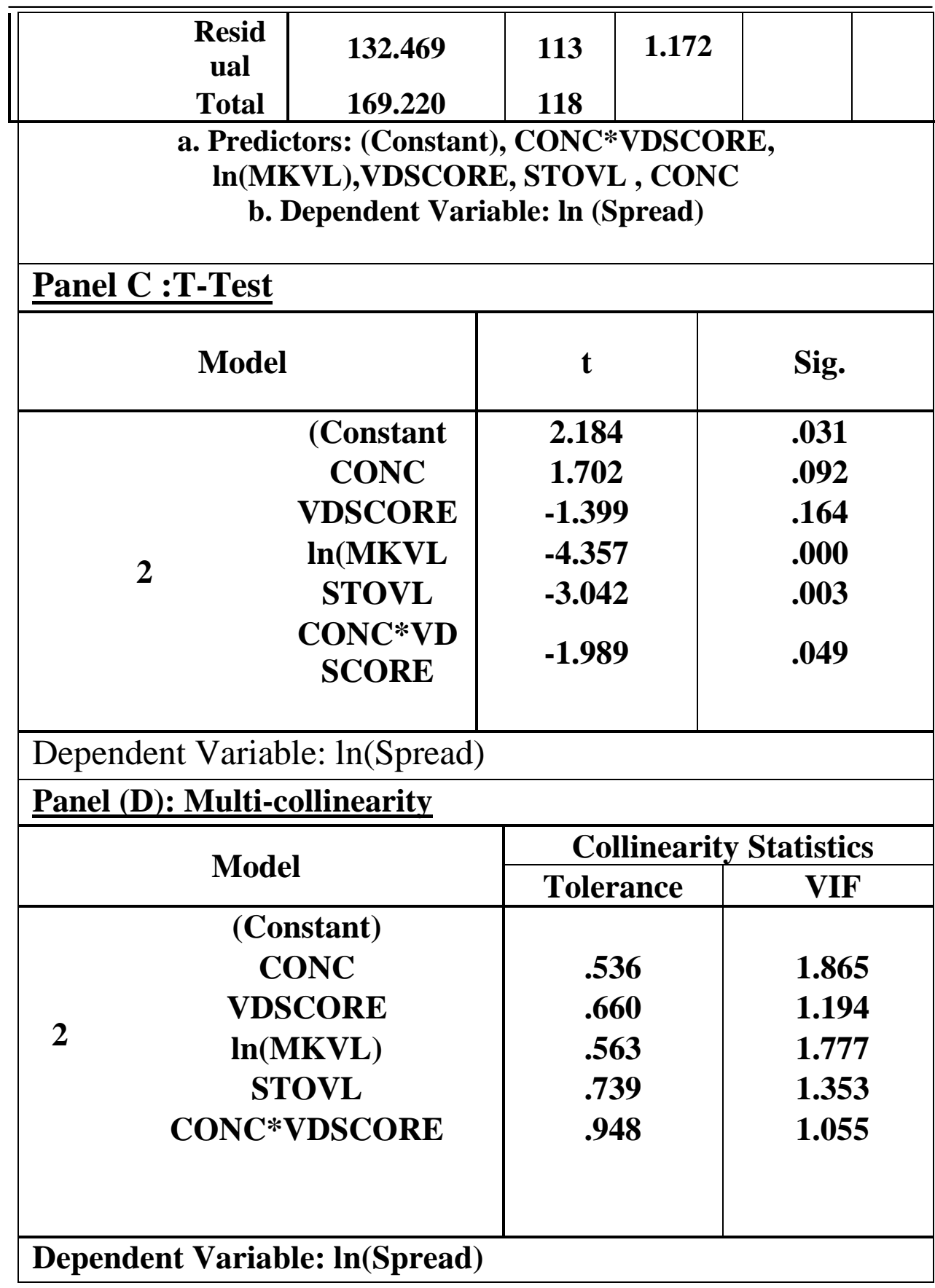

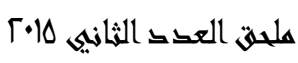


Investigating the Role of Voluntary Disclosure in Mitigating

Amira Bushra Ali Hassan

As illustrated through panel (A), the regression model explains around $(21.7 \%)$ of the total variation of information asymmetry. Panel (B) indicates that the regression model is statistically significant with $\mathrm{F}$ value (6.270), at a significance level less than (0.01). Panel (c) Shows the results of T-test for each independent variables. Except the voluntary disclosure, all the independent variables are statistically significant at sig value less or equal; (0.01) for both firm size and firm's stock liquidity, (0.05) for the interacting variable (CONC*VDSCORE) and (0.10) for ownership concentration. Panel (D) indicates that the independent variables has a tolerance value greater than $(0.2)$ and VIF value less than (5) which indicates that multi-collinearity is not problem.

\section{Summary and Conclusion}

This research aims to extent prior research in two ways. First it attempts to evaluate the role of ownership concentration as an internal corporate governance mechanism suggested by the literature to alleviate the conflict of interests and agency problems that arise from separation of ownership and control through measuring its impact on information asymmetry problem among equity investors in capital market. Second, the study shed the light on the role of voluntary disclosure in capital market through measuring its impact on information asymmetry problem specifically in concentrated ownership structures.

In order to achieve the main objectives of this research an ordinary least square regression was applied on data of a sample of 55 most actively traded companies listed on the Egyptian stock of exchange over the period (2009-2013). 
Investigating the Role of Voluntary Disclosure in Mitigating

Amira Bushra Ali Hassan

The data used in the study were obtained from various sources (i.e. Egyptian stock of exchange, Egypt Company for information dissemination).

Ownership concentration is measured using Herfindahl index which is calculated by summing up the squared percentage of shares owned by blockholder. Blockholder is defined as large shareholders who own more than five percent of campiness shares. A self constructed disclosure index was used to measure the level of voluntary disclosure on the annual reports of sample companies .

it is classified into five subcategories; (i)Strategic Information, (ii) Financial Information, (iii) key Non-Financial and Capital Market Information, (iv)Intangibles and Intellectual Capital Information, (v) Forward Looking Information. Items of the index were checked against the mandatory requirements under the Egyptian accounting standards and the disclosure rules issued by the Egyptian stock of exchange to ensure that the disclosure index only reflects voluntary items.

Two regression equations were estimated. The first equation examined the impact of ownership concentration on information asymmetry by classifying the concentrated ownership structures into two mutually exclusive classes based on the identity of large blockholders; (i) management controlled,(ii) institutional controlled ownership structure .

And examine the impact of each class on information asymmetry.

using the quoted bid ask spread as a proxy of information asymmetry and herfindahl index as a measure of the overall level 
Investigating the Role of Voluntary Disclosure in Mitigating

$\sim$ Amira Bushra Ali Hassan

of concentration, two dummy variables were created to identify the identity of large blockholders.

The findings revealed that ownership concentration in general is significantly positively associated with bid ask spread which indicate That more concentrated control by the largest shareholder increase the information asymmetry problem between controlling and minority shareholders which is consistent with prior studies of ( Byun, Hwang, \& Lee, 2011; Boujelbéne \& Bouri, 2011; Attig, et al., 2006).

The results are consistent with the adverse selection theory that ownership concentration could increase private information event, resulting in uniformed traders possibly facing a higher trading risk against informed traders who could exploit minority investors because of their superior access of timely information. The negative effect of ownership concentration is more sever for countries with relatively low levels of minority investor protection (Attig, et al., 2006). In such countries the existence of information asymmetry accompanied with the incentive and ability of controlling shareholder to expropriate wealth at the expense of minority shareholders would lead to a severe moral hazard problem. There is a lack of prior studies that incorporate the impact of concentration of ownership and the identity of blockholders.

The regression results of this research illustrated that the identity of large blockholder has no significant impact on information asymmetry. The results are inconsistent with the prior study of Jiang, Habib, \& Hub, (2011). 
Investigating the Role of Voluntary Disclosure in Mitigating

Amira Bushra Ali Hassan

The second regression model was applied to examine the role of voluntary disclosure as a moderator that would reduce the negative impact on ownership concentration on information asymmetry. The moderating variable was incorporated into the regression model through an interacting variable that result from multiplying ownership concentration by voluntary disclosure (Dawson, 2014).

The regression results revealed that voluntary disclosure play a significant role in mitigating information asymmetry in concentrated ownership structure as its existence in the regression model help to mitigate the negative impact of ownership concentration on information asymmetry.

In addition to the main research variables, the study took into consideration other important factors that might have a significant impact on information asymmetry according to the literature.

Two variables were incorporated into the two regression models as control variables, which are ; firm size measured by the natural log of firm 's market valuation, share turnover ratio as a proxy of firm 's stock liquidity. Their impact on information asymmetry was examined. The findings of two regression equations showed that both control variables are significantly negatively associated with the information asymmetry which is consistent with the prior literature ( e.g. Leuz \& Verrecchia, 2000; Yoon, Zo, \& Ciganek, 2011; Jiang, Habib, \& Hub, 2011; Cheng, courtenay, \& Krishnamurti, 2006; Petersen \& Plenborg,2006). 
Investigating the Role of Voluntary Disclosure in Mitigating

$\sim$ Amira Bushra Ali Hassan

\section{Recommendations}

The recommendations for future research could be summarized through the following points

- This research measured the voluntary disclosure using a disclosure index score calculated based on the quantity of information disclosed, future researches could focus on other attributes that are related to the qualitative characteristics of information disclosed (e.g. understandability, comparability, verifiability and timeliness) to assess the voluntary disclosure quality.

- This research measured the level of voluntary disclosure in regulated financial reports including financial statements, footnotes, management discussion \& analysis, board of directors' reports issued by the companies. in addition to, the disclosure books issued by the Egyptian Stock of Exchange , future researches may focus on internet financial reporting, conference calls, press releases as other forms of voluntary disclosure.

- This research used the relative quoted bid-ask spread as a proxy of information asymmetry. Future researches may apply other proxies (e.g. Probability of informed trading (PIN); Stock price volatility; relative effective bid-ask spread). Such proxies reflect the stock price informativeness. Future researches could also use more than one proxy for information asymmetry problem Based on the identity of large blockholders, 
$\sim$ Amira Bushra Ali Hassan

- This research classified concentrated ownership structures into two mutually exclusive classes which are management controlled and institutional controlled ownership structure. Future researches could focus on examing the impact of concentration of ownership on the hands of other controlling owners (i.e family members, governmental controlled ownership structures). 
Investigating the Role of Voluntary Disclosure in Mitigating

Amira Bushra Ali Hassan

\section{References}

Abdel-Fattah, T. (2008). Voluntary Disclosure Practices in Emerging Capital Markets:The Case of Egypt. Retrieved from Electronic Thesis Online Service (ETHOS), Durham University, (PHD) Dissertation.

Agarwal, P., \& O’Hara, M. (2007). Information Risk and Capital Structure.

Working paper, Cornell University.

Alchian, A. A., \& Demsetz, H. (1972). Production, Information Costs, and Economic Organization. American Economic Review, 62(5), 777 795.

Aly, D. A. (2008). Assessing the Development of Voluntary Internet Financial Reporting and disclosure in egypt, retrived from http://www.researchgate.net/publication/252649255,(PHD) Dissertation. Attig, N., Fong, W.-M., Yoser , G., \& Lang, L. H. (2006). Effects of Large Shareholding on Information Asymmetry and Stock Liquidity. Journal of Banking \& Finance, 30(10), 2875-2892.

Berle, A., \& Means. (1932). The Modern Corporation and Private Property. New York: The Macmillan.

Botosan, C. A. (1997). Disclosure Level and the Cost of Equity Capital. The Accounting Review, 72(2), 323-349.

Boujelbéne, N. B., \& Bouri, A. (2011). Ownership Structure and Stock Market Liquidity:Evidence from Tunisia. Int. J. Managerial and Financial Accounting, 3(1), 91-109.

Brown, S., Hillegeist, S. A., \& Lo, K. (2004). Conference Calls and Information Asymmetry. Journal of Accounting and Economics, 37(3), 343-366.

Byun, H.-Y., Hwang, L.-S., \& Lee, W.-J. (2011). How Does Ownership Concentration Exacerbate Information Asymmetry Among Equity Investors? Pacific-Basin Finance Journal, 19(5), 511-534.

Chen, W.-P., Chung, H., Lee, C., \& Liao, W.-L. (2007). Corporate Governance and Equity Liquidity: analysis of S\&P transparency and disclosure rankings. Corporate Governance: An International Review, 15(4), 644-660. 
Investigating the Role of Voluntary Disclosure in Mitigating

$\sim$ Amira Bushra Ali Hassan

Cheng, E. C., courtenay, S. M., \& Krishnamurti, C. (2006). The Impact of Increased Voluntary Disclosure on Market Information Asymmetry, Informed and Uninformed Trading. Journal of Contemporary Accounting \& Economics, 2(1), 33-72.

Clark, G. L., \& Wójcik, D. (2003). An Economic Geography of Global Finance: Ownership Concentration and Stock-Price Volatility in German Firms and Regions. Annals of the Association of American Geographers, 93(4), 909-924.

Clarkson, G., Jacobsen, T. E., \& Batcheller, A. L. (2007). Information Asymmetry and Information Sharing. Government Information Quarterly, 24(4), 827-839.

Connelly, B., Certo, S., Ireland, R., \& Reutzel, C. (2011). Signaling Theory: A Review and Assessment. Journal of Management, 37(1), 39-67.

Cormier, D., Ledoux, M.-J., Magnan, M., \& Walter Aerts. (2010). Corporate Governance and Information Asymmetry between Managers and Investors. Corporate Governance: The international journal of business in society, 10(5), 574 - 589.

Dawson, J. F. (2014). Moderation in Management Research: What, Why, When, and How. Journal of Business and Psychology, 29(1), 1-19.

Dyck, A., \& Zingales, L. (2004). Private Benefits of Control: An International Comparison. The Journal of Finance, 59(2), 537-600.

Eisenhardt, K. (1989). Agency Theory: An Assessment and Review. The Academy of Management Review, 14(1), 57-74.

Elsayed, M. O., \& Hoque, Z. (2010). Perceived International Environmental Factors and Corporate Voluntary Disclosure Practices: An Empirical Study. The British Accounting Review, 42(1), 17-35.

Eng, L., \& Mak, Y. (2003). Corporate Governance and Voluntary Disclosure. Journal of Accounting and Public Policy, 22(4), 325345.

Faccio, M., Larry H, P. L., \& Young, L. (2001). Dividends and Expropriation. The American Economic Review, 91(1), 54-79.

Fama, E. F., \& Jensen, M. C. (1983). Separation of Ownership and Control. Journal of Law and Economics, 26(2), 301-325. 
Investigating the Role of Voluntary Disclosure in Mitigating

$\sim$ Amira Bushra Ali Hassan

Fu, R., ArthurKraft, \& HuaiZhang. (2012). Financial reporting frequency,information asymmetry,and cost of equity. Journal of Accounting and Economics, 52(2-3), 132-149.

Gajewski, J.-F., \& Quéré, B. “. (2013). A Comparison of the Effects of Earnings Disclosures on Information Asymmetry: Evidence from France and the U.S. The International Journal of Accounting, 48(1), 1-25.

Gisbert, A., \& Navallas, B. (2013). The association between voluntary disclosure and corporate governance in the presence of severe agency conflicts. Advances in Accounting, incorporating Advances in International Accounting, 29(2), 286-298.

Hassan, O. A., Romilly, P., Giorgioni, G., \& Powerd, D. (2009). The Value Relevance of Disclosure: Evidence From the Emerging Capital Market of Egypt. The International Journal of Accounting, 44(1), 79-102.

Ho, P.-L., \& Taylor, G. (2013). Corporate Governance and Different Types of Voluntary Disclosure Evidence from Malaysian Listed Firms. Pacific Accounting Review, 25(1), 4-29.

Hossain, M., \& Hammami, H. (2009). Voluntary Disclosure in The Annual Reports of An Emerging Country: The Case of Qatar. Advances in Accounting, 25(2), 255-265.

Huafang, X., \& Jianguo, Y. (2007). Ownership Structure, Board Composition and Corporate Voluntary Disclosure: Evidence from Listed Companies in China. Managerial Auditing Journal, 22(6), 604-619.

Ismail, T. H., \& El-Shaib, N. M. (2012). Impact of market and organizational determinants on voluntary disclosure in Egyptian companies. Meditari Accountancy Research, 20(2), 113-133.

Jensen, M. C. (1994). self Interest, Altruism, Incentives, and Agency Theory. Journal of Applied Corporate Finance, 7(2), 40-45.

Jensen, M. C., \& Meckling, W. H. (1976). Theory of the Firm: Managerial Behavior, Agency Costs and Ownership Structure. 3(4), 305-360. 
Investigating the Role of Voluntary Disclosure in Mitigating

$\sim$ Amira Bushra Ali Hassan

Jiang, H., \& Habib, A. (2009). The Impact of Different Types of Ownership Concentration on Annual Report Voluntary Disclosures in New Zealand. Accounting Research Journal, 22(3), 275-304.

Jiang, H., Habib, A., \& Hub, B. (2011). Ownership Concentration, Voluntary Disclosures and Information Asymmetry in New Zealand. The British Accounting Review, 43(1), 39-53.

Khorramin, M., Asghari, A. W., \& Nia, G. A. (2014). Relationship between Ownership Concentration and Information Asymmetry on Listed Companies at Tehran Stock Exchange. Journal of Life Science and Biomedicine(JLSB), 4(1), 57-63.

Kumar, G. (2013). Voluntary disclosures of intangibles information by U.S.-listed Asian companies. Journal of International Accounting, Auditing and Taxation, 22(2), 109-118.

Lakhal, F. (2008). Stock Market Liquidity and Information Asymmetry Around Voluntary Earnings Disclosures New Evidence from France. International Journal of Managerial, 4(1), 60-75.

Leuz, C., \& Verrecchia, R. E. (2000). The Economic Consequences of Increased Disclosure. Journal of Accounting Research, 38, 91-124.

Petersen, C., \& Plenborg, T. (2006). Voluntary disclosure and Information Asymmetry In Denmark. Journal of International Accounting, Auditing and Taxation, 15(2), 127-149.

Samaha, K., \& Dahawy, K. (2011). An empirical analysis of corporate governance structures and voluntary corporate disclosure in volatile capital markets: the Egyptian experience. International Journal of Accounting, Auditing and Performance Evaluation, 7(1-2), 61-93.

Samaha, K., Dahawy, K., Hussainey, K., \& Stapleton, P. (2012). The extent of corporate governance disclosure and its determinants in a developing market: The case of Egypt. Advances in Accounting, incorporating Advances in International Accounting, 28(1), 168178.

Shleifer, A., \& Vishny, R. W. (1997). The Limits of Arbitrage. The Journal of Finance, 52(1), 35-55. 
Investigating the Role of Voluntary Disclosure in Mitigating

$\sim$ Amira Bushra Ali Hassan

Soliman, M. M. (2013). Firm Characteristics and the Extent of Voluntary Disclosure: The Case of Egypt. Research Journal of Finance and Accounting, 4(17), 71-80.

Stiglitz, J. E. (2002). Information and the Change in the Paradigm in Economics. The American Economic Review, 92(3), 460-501.

Uyar, A., \& Kılıç, M. (2012). Value Relevance of Voluntary Disclosure: Evidence from Turkish Firms. Journal of Intellectual Capital, 13(3), 363 - 376.

Yoon, H., Zo, H., \& Ciganek, A. P. (2011). Does XBRL Adoption Reduce Information Asymmetry? Journal of Business Research, 64(2), 157-163.

\section{Endnotes}

1. 1Blockholder : large shareholders who own $5 \%$ or more of company's outstanding shares

2. 2VDSCORE was included in the regression model to examine its impact as an independent variable that might affect bid- ask spread before examining its impact as moderator that might affect the relationship between ownership concentration and information asymmetry

3. 3The results of the first regression equation show the coefficient on VDSCORE is significantly negative. However, the results of the second regression show that although the coefficient on the interactive term CONC ${ }^{*}$ SDSCORE is significantly negative the coefficient on VDSCORE becomes insignificant. This indicates that the effect of disclosure on information asymmetry is strongly dependent on their corporate ownership structure. 